\begin{tabular}{l|c|c}
\hline ISSN: 0001-5113 & ACTA ADRIAT., & SHORT COMMUNICATION \\
AADRAY & $59(2): 207-212,2018$ & \\
\hline
\end{tabular}

DOI:10.32582/aa.59.2.5.

\title{
First record of the invasive green alga Codium fragile ssp. fragile (Chlorophyta, Bryopsidales) in Abruzzi waters, central Adriatic Sea
}

\author{
Giancarlo BELLISSIMO ${ }^{1 *}$, Francesca GALFO ${ }^{1}$, Andrea NICASTRO ${ }^{1}$, \\ Roberto COSTANTINI ${ }^{2}$ and Luca CASTRIOTA ${ }^{3}$ \\ ${ }^{1}$ Regional Agency for Environmental Protection of Sicily (ARPA Sicilia), Via Partanna \\ Mondello 50/A, 90147 Palermo, Italy \\ ${ }^{2}$ Via Risorgimento 14, Silvi Marina (Te), Italy \\ ${ }^{3}$ Institute for Environmental Protection and Research (ISPRA), Lungomare Cristoforo \\ Colombo n. 4521 (ex complesso Roosevelt), Località Addaura, 90149 Palermo, Italy \\ *Corresponding author, e-mail: gbellissimo@arpa.sicilia.it
}

The authors report for the first time on the invasive green alga Codium fragile ssp. fragile (Suringar) Hariot from the Adriatic coast of the Abruzzi Region of Italy (central Adriatic Sea). Several thalli have been found stranded on the beach of Silvi Marina since November 2015. This species, native to East Asia, has widely invaded several locations of the Mediterranean where it has been probably introduced through boating or shellfish aquaculture.

Key words: central Adriatic Sea, Codium fragile ssp. fragile, first record, introduced species

\section{INTRODUCTION}

The introduction and spread of invasive marine species into new environments, unintentional or deliberate, have become an increasing problem worldwide, with impacts on the biodiversity and ecosystem functioning and native communities (WILLIAMSON, 1996; GROSHOLZ, 2002). Nowadays, most biological invasions result from intensive human activities in the marine environment. In particular, aquaculture, fishing and interoceanic shipping have been widely accepted as causes and vectors of biological introductions (BOUDOURESQUE \& VERLAQUE, 2002;
RIBERA SIGUAN, 2003). The introduction of alien marine species has stimulated renewed attention on environmental management policy in various international frameworks for monitoring marine biodiversity and ecosystems. The Descriptor 2: "Non-indigenous species introduced by human activities are at levels that do not adversely alter the ecosystems" of the EU Marine Strategy Framework Directive (2008/56/CE) is actually one of the eleven qualitative descriptors for achieving the 'Good Environmental Status' (GES) of all marine waters by 2020 .

Codium fragile ssp. fragile (Suringar) Hariot is a coastal and estuarine species native to East 
Asia (Japan and Korea). In general, C. fragile ssp. fragile, known commonly as dead man's fingers, is considered to have ten subspecies (GUIRY \& GUIRY, 2017), three of which (including $C$. fragile ssp. fragile) are recognized as invasive in several parts of the globe (PROVAN et al., 2008).

The species $C$. fragile ssp. fragile, hereafter referred to as $C$. fragile, is a cosmopolitan species widely distributed throughout all three major oceans (GUIRY \& GUIRY, 2017). It was discovered along the Atlantic European coasts around 1900 (SILVA, 1955). Later, it has spread across Europe entering the Mediterranean Sea where it was recorded for the first time in France in 1946 (VERLAQUE, 1994) and in Italy in the Faro Lake (Sicily) in 1974 (FURNARI, 1974) as C. fragile ssp. tomentosoides (van Goor) P.C. Silva. The potential vectors of introduction and dispersal of $C$. fragile in the Mediterranean Sea have been recognized as fouling of ship hulls and importation of Asian shellfish (ZENETOS et al., 2012). The successful invasion of $C$. fragile has been related to its wide physiological tolerance together with different establishment categories like pollutant tolerance, reproductive mode (sexual, parthenogenetic and vegetative), growth strategies and grazing defence mechanism (FALACE et al., 2010). Considering that $C$. fragile can become a dominant canopy species in invaded habitats causing a nuisance to humans activities (CHERIF et al., 2016), tracing its spreading may be useful to control and prevent potential adverse effects on local ecosystems. This note refers to the first record of $C$. fragile in Abruzzi waters, which represents the southernmost record on the Italian coasts of the Adriatic Sea. Specifically, a description of morphological thallus features and anatomical utricle characters is provided.

\section{MATERIAL AND METHODS}

On 3 November 2015, one of the authors (RC) found and photographed a thallus of the macroalga identified as $C$. fragile stranded on the beach of Silvi Marina (central Adriatic Sea, $42^{\circ} 33^{\prime} 54^{\prime \prime} \mathrm{N}-14^{\circ} 06^{\prime} 25^{\prime}$ ' E, Fig. 1). The finding of this subspecies was confirmed again on the

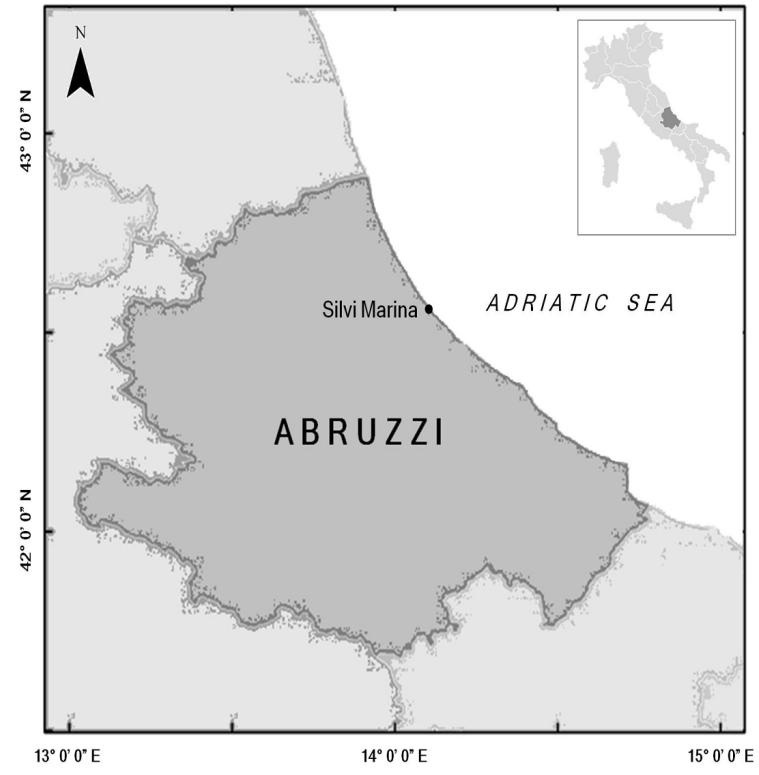

Fig. 1. New location of Codium fragile ssp. fragile along the coast of Abruzzi (central Adriatic Sea)

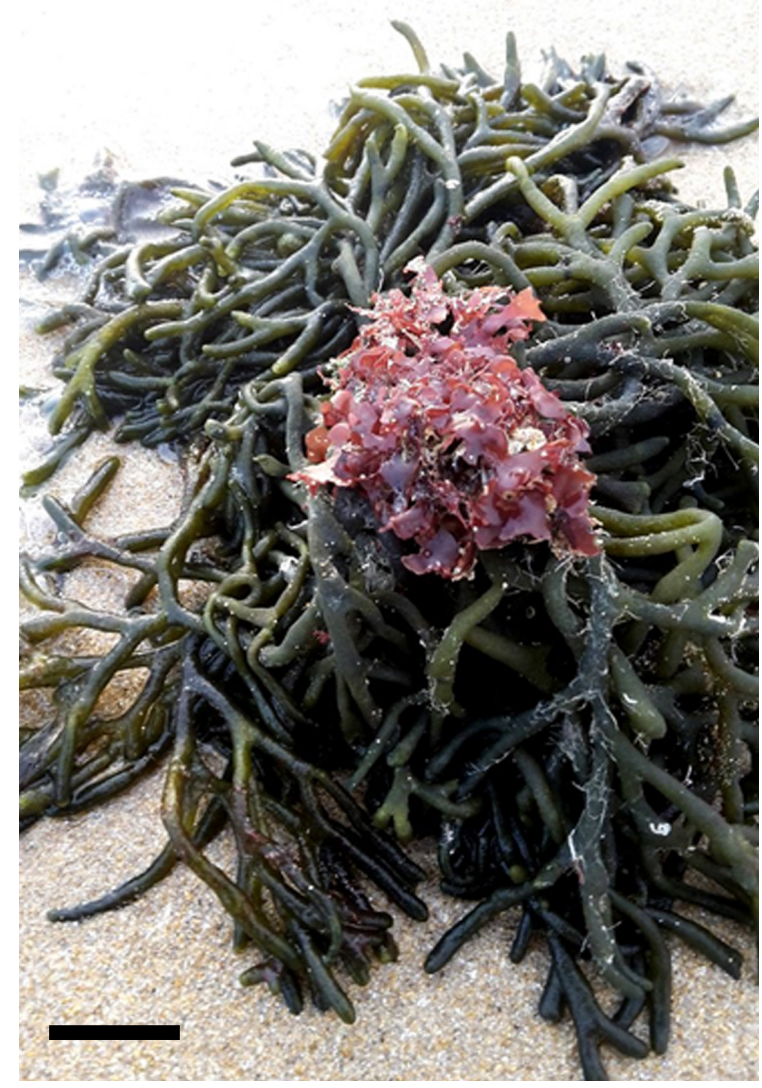

Fig. 2. Specimen of C. fragile ssp. fragile stranded on the beach of Silvi Marina (Abruzzi) on August 2017 (scale bar: $2 \mathrm{~cm}$ ). (Photo: R. Costantini) 
same beach in April 2016, October 2016 and August 2017 (Fig. 2). The coastal zone facing the stranding area is a sandy bottom also featuring rocks at shallow depths and hosts the biocenosis of fine well-sorted sands (CASTRIOTA et al., 2012). At depths ranging from 14 to $18 \mathrm{~m}$, at about $5 \mathrm{~km}$ from the coast, submerged artificial reefs run parallel to the shoreline at few kilometres both north and south of the sampling area (GIANSANTE et al., 2010); breakwaters are also present both north and south of this area at a few hundred meters from the coast.

Collected samples were sealed in individual plastic bags and immediately preserved in 70\% alcohol solution for subsequent identification. In the laboratory, thalli were cleaned with seawater to remove the maximum of epiphytes, and were observed using both an inverted microscope Leica DMi8 and a stereomicroscope Discovery. V20 (Zeiss). To determine the subspecies of $C$. fragile, the morphometric data were examined following the keys reported in the literature (SILVA, 1955; TROWBRIDGE, 1998; HUBBARD \& GARBARY, 2002; CORMACI et al., 2014). Voucher specimens were deposited in the personal herbarium of the first author at the Regional Agency for Environmental Protection of Sicily in Palermo (ARPA SICILIA - Unità Operativa Complessa ST3).

\section{RESULTS AND DISCUSSION}

Macroscopic and microscopic diagnostic characters of plants collected in this study matched with the descriptions of European specimens reported in the literature (see CHERIF et al., 2016 and references therein). Macroscopically, our thalli of $C$. fragile were dark green in colour, ranging from 18 to $25 \mathrm{~cm}$ high, and composed of spongy and cylindrical fronds dichotomously branched, $0.5-1.0 \mathrm{~cm}$ in diameter, fixed by a spongy, basal holdfast (Fig. 3). Internal structure consisted of interwoven filaments ending in a layer of siphonous swellings, called utricles that were tightly compressed together. Microscopic details of thalli revealed that utricles were usually more or less cylindrical (190-230 $\mu \mathrm{m}$ wide and 680-790 $\mu \mathrm{m}$ long) with a distinct

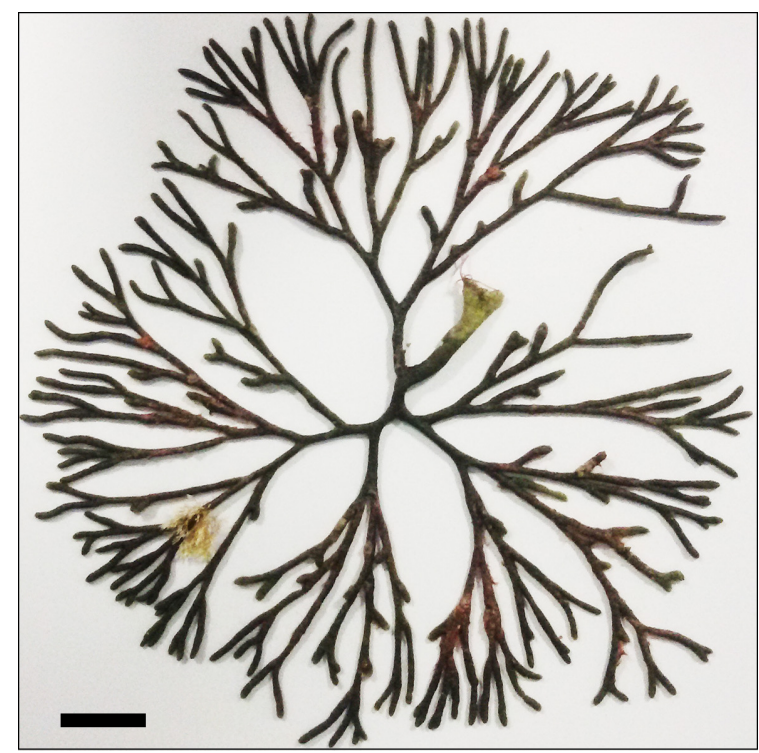

Fig. 3. Herbarium specimen of C. fragile ssp. fragile stored in the personal herbarium of G. Bellissimo at the Regional Agency for Environmental Protection of Sicily in Palermo (Unità Operativa Complessa ST3) (scale bar: $3 \mathrm{~cm}$ ). (Photo: G. Bellissimo)

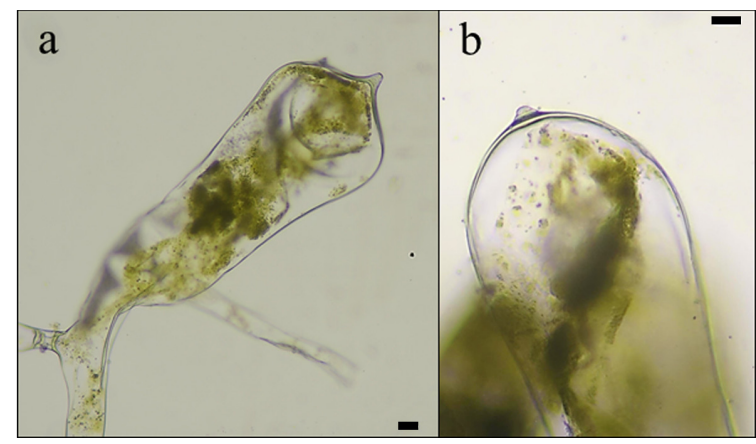

Fig. 4. Utricles of C. fragile ssp. fragile: a) pointed mucron; b) roundish mucron (scale bar: $50 \mu \mathrm{m}$ ). (Photo: F. Galfo)

constriction in the middle. The apex of the utricles was rounded and characterized by the presence of pointed and occasionally roundish mucrons (28.6-50.6 $\mu \mathrm{m}$ long), confirming the identification of this subspecies (Fig. 4). Oblong gametangia (75-85 $\mu \mathrm{m}$ wide and 240-290 $\mu \mathrm{m}$ long), one per fertile utricle, born laterally on the sub-apical parts of utricle, were found only in the specimens collected in October 2016 and in August 2017.

Codium fragile is one of the most important invasive marine algae becoming a dominant component of invaded habitats with dramatic ecological consequences on native understo- 
rey assemblages (CARLTON \& SCANLON, 1985; SCHEIBLING \& ANTHONY, 2001). Recent studies indicated that the expansion and establishment of $C$. fragile have been likely favoured by the presence of hard coastal defence structures (e.g. breakwaters and seawalls), by providing novel and suitable habitats for its colonization and persistence (BULLERI \& AIROLDI, 2005; BULLERI et al., 2007). Along the north-east coast of the Adriatic Sea, where human-made structures have proliferated to control the erosion of sandy beaches, $C$. fragile is one of 14 macrophytes introduced in the last three decades (ORLANDO-BONACA, 2010), representing an important component of low intertidal assemblages of these habitats (BULLERI et al., 2006). Although $C$. fragile was found only stranded on the beach, the high frequency of its findings recorded throughout the year let us think that it has settled on the nearby breakwaters occurring in the area. This leads to hypothesize it probably was carried from the surface currents of the north Adriatic Sea through vegetative propagation that plays a key role in long-distance dispersal (WATANA$\mathrm{BE}$ et al., 2009). However, this species was not previously reported among the components of marine flora along the Abruzzi coast (FURNARI et al., 2010), thus suggesting that the colonization on artificial habitats is recent and confirming its rapid spread.

\section{CONCLUSIONS}

The significance of invasive species in marine ecosystems worldwide has been discussed intensively in recent years from different ecological and economic points of view considering their complex and multilevel impacts on the introduced ecosystems. The knowledge of nonindigenous species status and their spreading in coastal areas is essential for an effective management of such habitats in order to plan appropriate strategies for protection and conservation of biodiversity.

Thus, additional studies have to be performed on this alien alga, integrating the existing information with a field survey in order to investigate about distribution, abundance, dynamics and impacts on marine environment and identify some of mechanisms underlying its successful establishment.

\section{REFERENCES}

BOUDOURESQUE, C.F. \& M. VERLAQUE. 2002. Biological pollution in the Mediterranean Sea: invasive versus introduced macrophytes. Mar. Pollut. Bull., 44: 32-38.

BULLERI, F. \& L. AIROLDI. 2005. Artificial marine structures facilitate the spread of a nonindigenous green alga, Codium fragile ssp. tomentosoides. J. Appl. Ecol., 42: 1063-1072.

BULLERI, F., M. ABBIATI \& L. AIROLDI. 2006. The colonisation of artificial human-made structures by the invasive alga Codium fragile ssp. tomentosoides in the north Adriatic Sea (NE Mediterranean). Hydrobiologia, 555: 263-269.

BULLERI, F., M.G. BRANCA, M. ABBIATI \& L. AIROLDI. 2007. Development of reproductive structures in the introduced green alga, Codium fragile ssp. tomentosoides, in the northern Adriatic Sea. Eur. J. Phycol., 42: 137-144

CARLTON, J.T. \& J.A. SCANLON. 1985. Progression and dispersal of an introduced alga: Codium fragile ssp. tomentosoides (Chlorophyta) on the Atlantic coast of North America. Bot. Mar., 28: 155-165.

CASTRIOTA, L., F. ANDALORO, R. COSTANTINI \& A. DE ASCENTIIS. 2012. First record of the Atlantic crab Callinectes sapidus Rathbun, 1896 (Crustacea: Brachyura: Portunidae) in Abruzzi waters, central Adriatic Sea. Acta Adriat., 53(3): 467-471.

CHERIF, W., L. KTARI, M. EL BOUR, A. BOUDABOUS \& M. GRIGNON-DUBOIS. 2016. Codium fragile subsp. fragile (Suringar) Hariot in Tunisia: morphological data and status of knowledge (Note). Algae, 31(2): 129-136. 
CORMACI, M., G. FURNARI \& G. ALONGI. 2014. Flora marina bentonica del Mediterraneo: Chlorophyta. Boll. Accad. Gioenia Sci. Nat. (Catania), 47: 11-436.

FALACE, A., G. ALONGI, M. CORMACI, G. FURNARI, D. CURIEL, E. CECERE \& A. PETROCELLI. 2010. Changes in the benthic algae along the Adriatic Sea in the last three decades. Chem. Ecol. 26: (S1): 77-90.

FURNARI, G. 1974. Segnalazione di Codium fragile (Suringar) Hariot nel Lago di Faro (Messina). Mem. Biol. Mar. Oceanogr., 4: 193-198. FURNARI, G., G. GIACCONE, M. CORMACI, G. ALONGI, M. CATRA, A. NISI \& D. SERIO. 2010. Macrophytobenthos. In: Checklist della flora e della fauna dei mari italiani (Parte II). G. Relini (Editor). Biol. Mar. Medit., 17(S1): 801-828.

GIANSANTE, C., M. FATIGATI, F. CIARROCCHI, G.S. MILILLO, L. ONORI \& N. FERRI. 2010. Monitoring of ichthyic fauna in artificial reefs along the Adriatic coast of the Abruzzi Region of Italy. Vet. Ital., 46(3): 365-374.

GROSHOLZ, E. 2002. Ecological and evolutionary consequences of coastal invasions. Trends Ecol. Evol., 171: 22-27.

GUIRY, M.D. \& G.M. GUIRY. 2017. AlgaeBase. World-wide electronic publication, National University of Ireland, Galway, Available from: http://www.algaebase.org. Accessed Oct 4, 2017.

HUBBARD, C.B. \& D.J. GARBARY. 2002. Morphological variation of Codium fragile (Chlorophyta) in eastern Canada. Bot. Mar., 45: 476-485.

ORLANDO-BONACA, M. 2010. New records of non-indigenous algal species in Slovenian coastal waters. Ann. Ser. Hist. Nat., 20: 143150.

PROVAN, J., D. BOOTH, N.P. TODD, G.E. BEATTY \& C.A. MAGGS. 2008. Tracking biological invasions in space and time: elucidating the invasive history of the green alga Codium fragile using old DNA. Divers. Distrib., 14: 343-354.
RIBERA SIGUAN, M.A. 2003. Pathways of biological invasions of marine plants. In: G.M. Ruiz and J.T. Carlton (Editors). Invasive species: vectors and management strategies. Washington DC, Island Press, pp. 183-226.

SCHEIBLING, R.E. \& S.X. ANTHONY. 2001. Feeding, growth and reproduction of sea urchins (Strongylocentrotus droebachiensis) on single and mixed diets of kelp (Laminaria spp.) and the invasive alga Codium fragile ssp. tomentosoides. Mar. Biol., 139: 139-146.

SILVA, P.C. 1955. The dichotomous species of Codium in Britain. J. Mar. Biol. Assoc. U.K., 34: 565-577.

TROWBRIDGE, C.D. 1998. Ecology of the green macroalga Codium fragile (Suringar) Hariot 1989: invasive and non-invasive subspecies. Oceanogr. Mar. Biol.: An Annual Review, 36: $1-64$.

VERLAQUE, M. 1994. Inventaire des plantes marines introduites en Méditerranée: origines et répercussions sur l'environnement et les activités humaines. Oceanol. Acta, 17: 1-23.

WATANABE, S., A. METAXAS \& R.E. SCHEIBLING. 2009. Dispersal potential of the invasive green alga Codium fragile ssp. fragile. J. Exp. Mar. Biol. Ecol., 381: 114-125.

WILLIAMSON, M.H. 1996. Biological Invasions. Chapman \& Hall, London, New York.

ZENETOS, A., S. GOFAS, C. MORRI, A. ROSSO, D. VIOLANTI, J.E. GARCÍA RASO, M.E. ÇINAR, A. ALMOGI-LABIN, A.S. ATES, E. AZZURRO, E. BALLESTEROS, C.N. BIANCHI, M. BILECENOGLU, M.C. GAMBI, A. GIANGRANDE, C. GRAVILI, O. HYAMS-KAPHZAN, P.K. KARACHLE, S. KATSANEVAKIS, L. LIPEJ, F. MASTROTOTARO, F. MINEUR, M.A. PANCUCCI-PAPADOPOULOU, A. RAMOS ESPLÁ, C. SALAS, G. SAN MARTÍN, A. SFRISO, N. STREFTARIS \& M. VERLAQUE. 2012. Alien species in the Mediterranean Sea by 2012: a contribution to the application of European Union's Marine Strategy Framework Directive (MSFD). Part 2. Introduction trends and pathways. Mediterr. Mar. Sci., 13: 328-352. 


\title{
Prvi nalaz invazivne zelene alge Codium fragile ssp. fragile (Chlorophyta, Bryopsidales) u vodama talijanske pokrajine Abruzzi, srednji Jadran
}

\author{
Giancarlo BELLISSIMO*, Francesca GALFO, Andrea NICASTRO, Roberto COSTANTINI \\ i Luca CASTRIOTA
}

*Kontakt e-mail: gbellissimo@arpa.sicilia.it

\section{SAŽETAK}

Autori izvješćuju po prvi put o nalazu invazivne zelene alge Codium fragile ssp. fragile (Suringar) Hariot s jadranske obale talijanske pokrajine Abruzzo (središnji Jadran). Nekoliko talija je pronađeno na plaži u mjestu Silvi Marina u studenom 2015. godine. Ova vrsta, porijeklom iz istočne Azije, se rasprostranila na nekoliko Sredozemnih lokacija gdje je vjerojatno unesena plovilom ili akvakulturom školjkaša.

Ključne riječi: središnje Jadransko more, Codium fragile ssp. fragile, prvi nalaz, unesene vrste 